Bull. Mater. Sci., Vol.4, No. 5, December 1982, pp. 527-548 O Printed in India.

\title{
Crystal growth in gel media
}

\author{
A R PATEL and A VENKATESWARA RAO* \\ Department of Physics, Sardar Patel University, Vallabh Vidyanagar 388 120, India \\ -Present Address : Department of Physics, Shivaji University, Kolhapur 416 004, India \\ MS received 18 February 1981 ; revised 9 February 1982
}

\begin{abstract}
An attempt has been made in this review to cover the existing information on the growth of single crystals in gels. Preparation of various types of gels, in which crystals can be grown, has been briefly described. The growth of single crystals from gels is reviewed using the following classifications: (i) Crystal growth by reaction. (ii) Crystallization by complex dilution method. (iii) Crystal growth by reduction of solubility. A compact list of some important crystals grown in gels is given. Growth mechanism and nucleation problems are discussed. Morphologies of various gel-grown crystals are described. Researches on gel-grown single crystals are also briefly described.
\end{abstract}

Keywords. Gel growth ; nucleation ; growth mechanism ; morphologies; crystal growth ; complex dilution method; nucleation control ; habit modification.

\section{Introduction}

While crystal growth from aqueous, organic and salt solutions has been studied for a number of years, it is only since 1965 that a systematic research work on crystal growth in gels has been undertaken. In recent years considerable attention has been drawn towards such work and the number of research centres engaged in such investigations has increased. Modern technology badly needs perfect single crystals having various valuable properties such as those of semiconductors, luminophores, piezoelectrics, dielectrics and so on. Single crystals are expected to be of high perfection of crystalline structure, $i$. e. no more than a small number of defects such as deformation of growth forms, dislocations, etc.

In the first place such criteria are satisfied when single crystals are grown under the most favourable conditions. In this respect high melting point and water insoluble substances are the most difficult to grow because at the melting temperature they react with silica or other container materials and are insoluble in water. The same is true for substances that decompose on melting, especially those 
including volatile components. When gels are used the requirements for the crystallization process are less rigid, and growth from gels at room temperature (20 to $40^{\circ} \mathrm{C}$ ) leads to better single crystals.

The growth of single crystals in gels has received considerable importance since Liesegang (1896) first observed the periodic precipitation of slightly soluble salts in gelatin. These "Liesegang rings" inspired many other chemists and also mineralogists to study other reactions in various colloids. Among the early workers were Hatschek (1911), Holmes (1917), Fells and Firth (1926), Fisher and Simons (1926), Morse and Donnay (1931) etc. Interest in the method was revived by Stong (1962) and soon thereafter, Vand et al (1963) described the full potential of growing single crystals in gels. Later, Henisch et al (1965) published detailed procedures for growing a variety of single crystals in gels.

The gel method has the following advantages over other crystal growth methods and hence it is fully explored.

(i) It is well-known that crystals grown at room temperature $\left(20\right.$ to $\left.40^{\circ} \mathrm{C}\right)$ will have lower concentrations of non-equilibrium defects than those grown at elevated temperatures.

(ii) Crystals can be observed practicaily in all stages of growth.

(iii) All crystals are delicately held in the position of their formation, thus limiting effects due to impact on the bottom or sides of the container.

(iv) All nuclei are spatially separated, minimizing precipitation.

(v) The procedure can be conveniently used for mass production of crystals.

(vi) Crystals with different morphologies and sizes can be obtained by changing the growth conditions.

(vii) The method is extremely simple and inexpensive.

\section{Preparation of various type of gels}

Gels can be prepared using a wide variety of techniques and materials. Preparation, advantages and disadvantages of various types of geis, used for crystal growth are given in table 1 .

\section{Crystal growth}

The enormous flow of information related to crystal growth in gels has been divided into the following three basic parts, each of which has special advantages which are described in what follows. (i) Crystal growth by reaction; (ii) Crystallization by complex dilution method; and (iii) Crystal growth by reduction of solubility. 
Table 1. Gel media used for crystal growth.

\begin{tabular}{|c|c|c|c|c|}
\hline & Gel Preparation & Advantages & Disadvantages & References \\
\hline 1. & $\begin{array}{l}\text { Silica: Mix aqueous } \\
\text { solutions of sodium } \\
\text { silicate or sodium } \\
\text { metasilicate (sp. gr. } \\
1 \cdot 03-1 \cdot 06 \text { ) and acid } \\
(1 \text { to } 4 \mathrm{~N} \text { of mineral } \\
\text { or organic). }\end{array}$ & $\begin{array}{l}\text { 1. Better crystallinity } \\
\text { of product in } \\
\text { gel } \\
\text { (sp. gr. 1.03) }\end{array}$ & $\begin{array}{l}\text { 1. } \mathrm{SiO}_{2} \text { inclusion } \\
\text { (in some crystals). }\end{array}$ & $\begin{array}{l}\text { Henisch et al } \\
\text { (1965) }\end{array}$ \\
\hline 2. & $\begin{array}{l}\text { Gelatin: Dissolve } 5 \\
\text { to } 6 \mathrm{gm} \text {. of gelatin } \\
\text { powder in water by } \\
\text { stirring at a constant } \\
\text { temperature of } 50^{\circ} \mathrm{C} \\
\text { for one hour and cool } \\
\text { to room temperature. } \\
\text { In order to strengthen } \\
\text { the gel addition of } 0.1 \\
\text { to } 1.0 \mathrm{ml} \text { of formal- } \\
\text { dehyde is necessary. }\end{array}$ & $\begin{array}{l}\text { 1. Great stability over } \\
\text { large pH range } \\
(3 \text { to } 10 \cdot 5) \\
\text { 2. Lack of interfer- } \\
\text { ing ions } \\
\text { 3. High optical clar- } \\
\text { ity. }\end{array}$ & $\begin{array}{l}\text { 2. Supports more } \\
\text { nucleation sites. }\end{array}$ & $\begin{array}{l}\text { Banks et al } \\
\text { (1973) }\end{array}$ \\
\hline 3. & $\begin{array}{l}\text { Agar - Dissolve } 1 \text { to } \\
5 \mathrm{gm} \text {. of agar powder } \\
\text { in water, boil it and } \\
\text { cool to room tempe- } \\
\text { rature. }\end{array}$ & 1. Easy workup. & $\begin{array}{l}\text { 1. Transparency of } \\
\text { gel decreases as } \\
\text { the concentration } \\
\text { of agar increases } \\
\text { 2. Inclusion of the } \\
\text { gel. }\end{array}$ & $\begin{array}{l}\text { Brezina and } \\
\text { Havrankova } \\
\text { (1971). }\end{array}$ \\
\hline 4. & $\begin{array}{l}\text { Clay (or Bentonite) : } \\
\text { Powdered clay slowly } \\
\text { sifted rapidiy stirred } \\
\text { water in a blender } \\
\text { until about } 9 \% \text { clay } \\
\text { had been added. Gel } \\
\text { sets immediately. }\end{array}$ & $\begin{array}{l}\text { 1. The morphology } \\
\text { of crystals grown } \\
\text { is similar to those } \\
\text { in many natural } \\
\text { occurrences. This } \\
\text { knowledge would } \\
\text { aid in solving } \\
\text { geologic problems. }\end{array}$ & $\begin{array}{l}\text { 1. Crystals generally } \\
\text { contain abundant } \\
\text { steps kinks and pits. } \\
\text { 2. Incorporation of clay } \\
\text { particles. }\end{array}$ & Cody (1976) \\
\hline 5. & $\begin{array}{l}\text { Polyacralamide : } \\
\text { Dissolve } 3.99 \text { wt. } \% \\
\text { of acrylamide and } \\
0.02 \text { wt. } \% \text { of the } \\
\text { cross-linking agent } \\
\text { in water, bubble } \\
\text { with nitrogen, degas } \\
\text { by lowering the } \\
\text { pressure. }\end{array}$ & $\begin{array}{l}\text { 1. It is more rigid and } \\
\text { transparent for } \\
\text { more than six } \\
\text { months in wide } \\
\text { range of } \mathrm{pH} \text { from } \\
0.2 \text { to } 13 .\end{array}$ & $\begin{array}{l}\text { 1. Preparation of gel } \\
\text { is more difficult } \\
\text { compared to other } \\
\text { gels. }\end{array}$ & $\begin{array}{l}\text { Brezina and } \\
\text { Havrankova. } \\
(1976)\end{array}$ \\
\hline
\end{tabular}

\subsection{Crystal growth by reaction}

Most of the work on crystal growth in gels has been done by the reaction method. It has a special advantage of growing single crystals which are insoluble 
(or slightly soluble) in water and which decompose before reaching their melting point. The requirements to grow single crystals by this method are (i) the reactants employed here must be soluble in the solvent (usually water) and the product crystal must be relatively less soluble, (ii) the gel must remain stable in the presence of the reacting solutions and must not react with these solutions or with the product formed, and (iii) some solubility of the product crystal is required in order to grow crystals of any size (Armington and O' Connor 1967).

In this method two soluble reactants are allowed to diffuse through a gel where they react and form an insoluble or relatively less soluble crystalline product. This may be done by the test tube technique, as shown in figure 1 , in which one of the reactants is incorporated inside the gel and the other reactant is diffused into it or by the U-tube technique (figure 2) or its modifications in which the two reactants are allowed to react by diffusion into an essentially inactive gel.

There are various crystallization apparatus used to grow single crystals by this method. The disadvantages of these crystallization apparatus include the depletion of one of the reactants which is inside the gel (Henisch et al 1965), the incorporation of reaction waste products by the growing crystals (Henisch et al 1965; Arend and Huber 1972; Patel and Venkateswara Rao 1977), supporting, handling and cleaning of the apparatus (Brezina and Havrankova 1976; Arend and Huber 1972; Patel and Bhat 1973; Blank 1973; Konak et al 1977; Martin and Haendler 1978) and preparation of gel inside the horizontal tube open at both the ends (Brezina and Havrankova 1976; Konak et al 1977; Martin and Haendler 1978). The improved design of modified gel-technique (figure 3) used by Patel and Venkateswara Rao (1980) eliminates all the inconveniences of the previous gel growth techniques and also permits the growth of mixed or doped crystals by multiple diffusion. A few single crystals of ferroelectric lead monohydrogen phosphate $\left(\mathrm{PbHPO}_{4}\right)$ grown by this method are displayed in figure 4 .

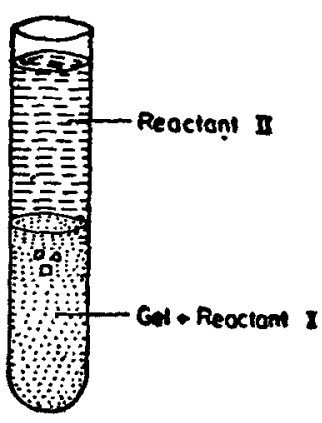

Figure 1. Schematic diagram of test tube apparatus for crystal growth by reaction method.

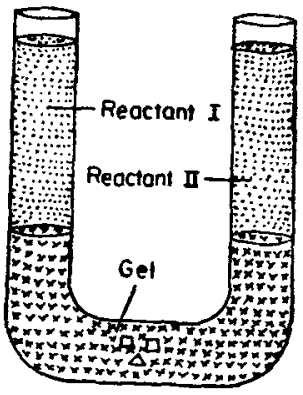

Figure 2. Schematic diagram of U-tube apparatus for crystal growth by reaction method.

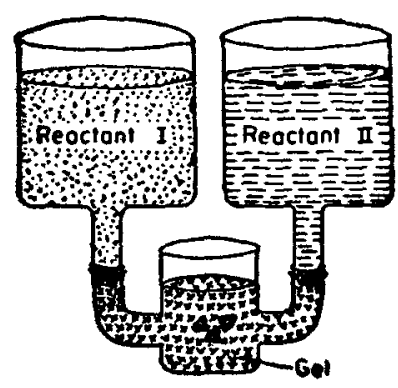

Figure 3. Schematic diagram of an improved design for crystal growth by reaction method (after Patel and Venkateswara Rao 1980). 
Table 2. Some crystuls grown by reaction

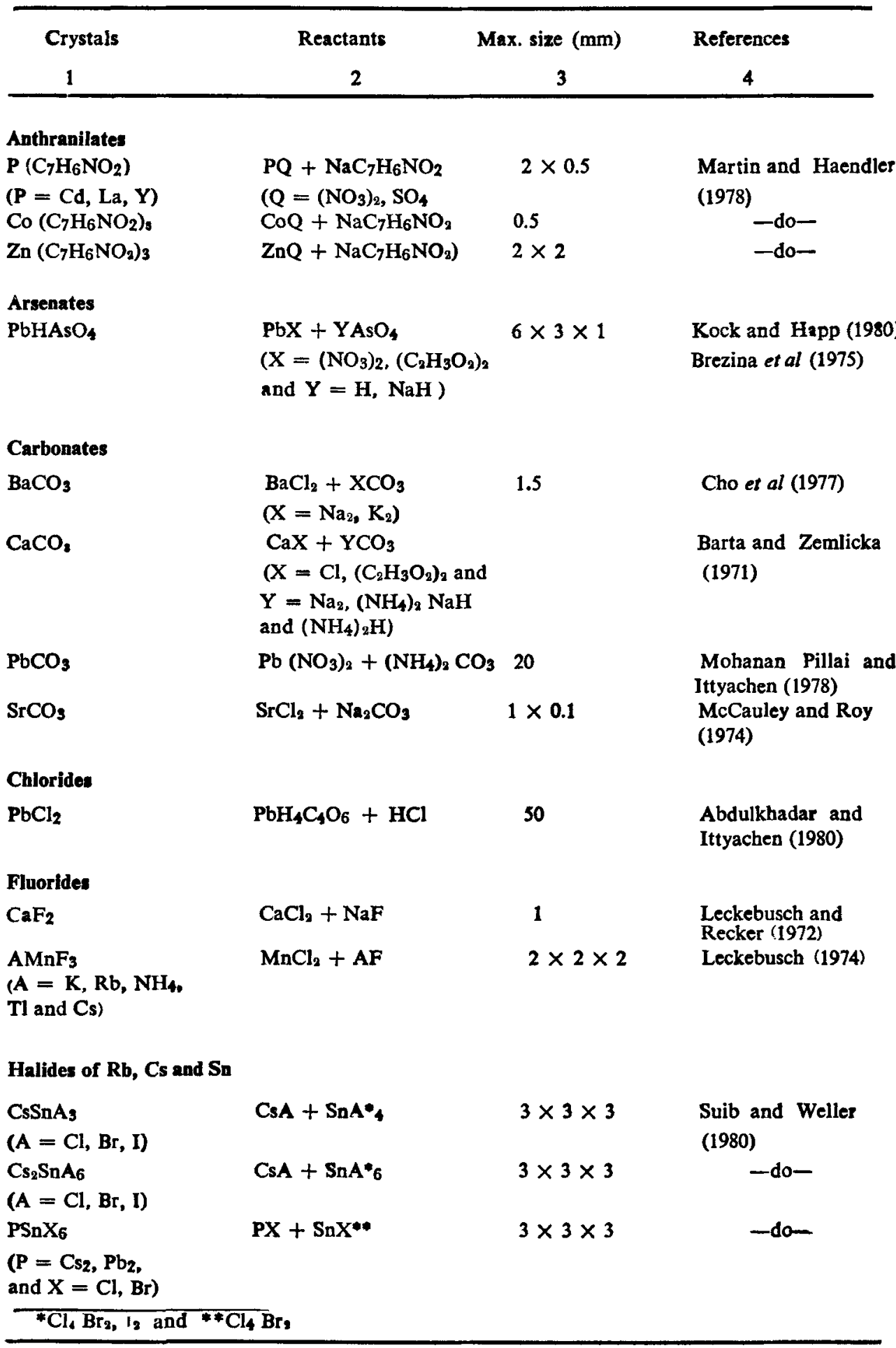


Table 2 (Contd.)

\begin{tabular}{|c|c|c|c|}
\hline 1 & 2 & 3 & 4 \\
\hline $\begin{array}{l}\mathrm{RbSnA}_{8} \\
(\mathrm{~A}=\mathrm{Cl}, \mathrm{Br}, \mathrm{I})\end{array}$ & $\mathrm{RbA}+\mathrm{SnA}^{*}{ }_{3}$ & $3 \times 3 \times 3$ & Suib and Weller (1980 \\
\hline $\begin{array}{l}\mathrm{RSn}_{2} \mathrm{I}_{4} \\
(\mathrm{R}=\mathrm{Cs}, \mathrm{Rb})\end{array}$ & $\mathrm{RI}+\mathrm{SnI}_{2}$ & $3 \times 3 \times 3$ & -do- \\
\hline \multicolumn{4}{|l|}{ Hexachlorides } \\
\hline $\mathrm{CsPdCl}_{6}$ & $\mathrm{H}_{2} \mathrm{PdCl}_{6}+2 \mathrm{CsCl}$ & 5 & Brouwer et al (1974) \\
\hline $\mathrm{Cs}_{2} \mathrm{PtCl}_{6}$ & $\mathrm{H}_{2} \mathrm{PtCl}_{6}+2 \mathrm{CsCl}$ & 4 & $-\mathrm{do}-$ \\
\hline $\mathrm{Cs}_{2} \mathrm{IrCl}_{6}$ & $\mathrm{H}_{2} \mathrm{IrCl}_{6}+2 \mathrm{CsCl}$ & 2 & - do- \\
\hline $\mathrm{K}_{2} \mathrm{PdCl}_{6}$ & $\mathrm{H}_{2} \mathrm{PdCl}_{6}+2 \mathrm{KCl}$ & 6 & $-\mathrm{do}-$ \\
\hline $\mathrm{Rb}_{2} \mathrm{PdCl}_{6}$ & $\mathrm{H}_{2} \mathrm{PdCl}_{6}+2 \mathrm{RbCl}$ & 7 & - do- \\
\hline $\mathrm{Rb}_{2} \mathrm{PtCl}_{6}$ & $\mathrm{H}_{2} \mathrm{PtCl}_{6}+2 \mathrm{RbCl}$ & 15 & $-\mathrm{do}-$ \\
\hline $\mathrm{Rb}_{2} \mathrm{IrCl}_{6}$ & $\mathrm{H}_{2} \mathrm{IrCl}_{6}+2 \mathrm{RbCl}$ & 3 & - do- \\
\hline \multicolumn{4}{|l|}{ Iodate: } \\
\hline $\mathrm{Ag}_{2} \mathrm{H}_{3} \mathrm{IO}_{6}$ & $\mathrm{AgNO}_{3}+\mathrm{H}_{6} \mathrm{IO}_{6}$ & $250 \mathrm{~mm}^{*}$ & $\begin{array}{l}\text { Arend and Huber } \\
\text { (1972) }\end{array}$ \\
\hline $\mathrm{Cu}\left(\mathrm{IO}_{3}\right)_{2}$ & $\mathrm{CuSO}_{4}+\mathrm{HIO}_{4}$ & 4 & Nassau et al (1973) \\
\hline $\mathrm{CuHgI}_{4}$ & $\begin{array}{l}(\mathrm{CuCl}+\mathrm{HCl})+ \\
\left(\mathrm{Hgl}_{2}+\mathrm{KI}\right)\end{array}$ & - & Chivian (1976) \\
\hline $\mathrm{Co}_{3}\left(\mathrm{IO}_{3}\right) .4 \mathrm{H}_{2} \mathrm{O}$ & $\mathrm{CoSO}_{4}+\mathrm{HIO}_{3}$ & 1 & $\begin{array}{l}\text { Shiever and Nassau } \\
\text { (1972) }\end{array}$ \\
\hline CsIs & $\mathrm{CsCl}+\mathrm{HIO}_{3}$ & - & $\begin{array}{l}\text { Armington and } \\
\text { O'Connor (1971 }\end{array}$ \\
\hline $\mathrm{KI}_{3}$ & $\mathrm{KCl}+\mathrm{HIO}_{3}$ & - & - do- \\
\hline $\begin{array}{l}3 \mathrm{La}\left(\mathrm{IO}_{3}\right)_{3} \mathrm{HIO}_{3} 7 \mathrm{H}_{2} \mathrm{O} \\
\left(\mathrm{Mn}\left(\mathrm{IO}_{3}\right)_{2}\right)\end{array}$ & $\begin{array}{l}\mathrm{La}\left(\mathrm{NO}_{3}\right)+\mathrm{HIO}_{3} \\
\mathrm{MnSO}_{4}+\mathrm{HIO}_{3}\end{array}$ & $\overline{1}$ & $\begin{array}{l}\text { Bernstein et al (1976) } \\
\text { Shiever and INassau } \\
\text { (1972) }\end{array}$ \\
\hline $\mathrm{Ni}\left(\mathrm{IO}_{3}\right)_{2}$ & $\mathrm{NiSO}_{4}+\mathrm{HIO}_{3}$ & 1 & $-\mathrm{do}-$ \\
\hline RbI3 & $\mathrm{RbCl}+\mathrm{HIO}_{3}$ & - & $\begin{array}{l}\text { Armington and } \\
\text { O'Connor (1971) }\end{array}$ \\
\hline $\mathrm{Ba}\left(\mathrm{IO}_{3) 2}\right.$ & $\mathrm{BaCl}_{2}+\mathrm{NaIO}_{3}$ & $1.5 \times 1 \times 1$ & Joshi and Trivedi\}(1980) \\
\hline $\mathrm{Ca}\left(\mathrm{IO}_{3}\right)_{2}$ & $\mathrm{CaCl}_{2}+\mathrm{NaIO}_{3}$ & $20 \times 4 \times 3$ & - do- \\
\hline $\mathrm{Sr}\left(\mathrm{IO}_{3}\right)_{2}$ & $\mathrm{SrCl}_{2}+\mathrm{NaIO}_{3}$ & $8 \times 5 \times 4$ & - do- \\
\hline
\end{tabular}

\section{Iodides}

\begin{tabular}{|c|c|c|c|}
\hline $\mathrm{CuI}$ & $\mathrm{CuSO}_{4}+\mathrm{KI}$ & $5 \times 5 \times 1$ & Nakada et al (1976) \\
\hline $\mathrm{PbI}_{2}$ & $\begin{array}{l}\mathrm{PbX}+\mathrm{YI} \\
\left(\mathrm{X}=\left(\mathrm{C}_{2} \mathrm{H}_{3} \mathrm{O}_{2}\right)_{2},\left(\mathrm{NO}_{3) 2}\right.\right. \\
\text { and } \mathrm{Y}=\mathrm{K}, \mathrm{Na}, \mathrm{H})\end{array}$ & $30 \times 25 \times 2$ & $\begin{array}{l}\text { Patel and Venkateswara } \\
\text { Rao (1980) }\end{array}$ \\
\hline T1I & $\mathrm{TINO}_{3}+\mathrm{NaI}$ & $0.2 \times 0.2$ & Shiojiri et al (1978) \\
\hline $\mathrm{SnI}_{2}$ & $\mathrm{SnCl}_{2}+\mathrm{KI}$ & $15 \times 1 \times 1$ & Thomas Abraham (1979) \\
\hline $\mathrm{SnI}_{4}$ & $\mathrm{SnCl}_{2}+\mathbf{K I}$ & $3 \times 2 \times 2$ & $\begin{array}{l}\text { Thomas Abraham (1979) } \\
\text { Desai and Rai (1980) }\end{array}$ \\
\hline
\end{tabular}


Table 2 (Contd.)

\begin{tabular}{lllll}
\hline 1 & 2 & 3 & 4 \\
\hline
\end{tabular}

Molybdates :

$\mathrm{BaMoO}_{4}$

$\mathrm{PbMoO}_{4}$

Oxalates :

$\mathrm{CdC}_{2} \mathrm{O}_{4}$

$\mathrm{CuC}_{2} \mathrm{O}_{4} \cdot \mathrm{H}_{2} \mathrm{O}$

$\mathrm{CoC}_{2} \mathrm{O}_{4} \cdot 2 \mathrm{H}_{2} \mathrm{O}$

$\mathrm{MnC}_{2} \mathrm{O}_{4} .2 \mathrm{H}_{2} \mathrm{O}$

$\mathrm{NaHC}_{2} \mathrm{O}_{4} \cdot \mathrm{H}_{2} \mathrm{O}$

\section{Perchlorates}

$\mathrm{KClO}_{4}$

$\mathrm{CsClO}_{4}$

$\mathrm{RbClO}_{4}$

\section{Phosphates}

$\mathrm{Ag}_{3} \mathrm{PO}_{4}$

$\mathrm{Ba}_{2}\left(\mathrm{PO}_{4}\right)_{2}$

$\mathrm{BaHPO}_{4}$

$\mathrm{BaNH}_{4} \mathrm{PO}_{4} .8 \mathrm{H}_{2} \mathrm{O}$

$\mathrm{CaHPO}_{4} \cdot 2 \mathrm{H}_{2} \mathrm{O}$

$\mathrm{MgNH}_{4} \mathrm{PO}_{4} 6 \mathrm{H}_{2} \mathrm{O}$

$\mathrm{PbHPO}_{4}$

$\mathrm{Pb}_{4}\left(\mathrm{NO}_{3}\right)_{2}\left(\mathrm{PO}_{4}\right)_{2}$ $2 \mathrm{H}_{2} \mathrm{O}$

$\mathrm{Sr}_{3}\left(\mathrm{PO}_{4}\right)_{2}$

$\mathrm{SrHPO}_{4}$

$\mathrm{SrNH}_{4} \mathrm{PO}_{4} .8 \mathrm{H}_{2} \mathrm{O}$

\section{Selenates}

$\mathrm{Ag}_{2} \mathrm{SeO}_{4}$

$\mathrm{Bi}_{2}\left(\mathrm{SeO}_{4}\right)_{3}$

$\begin{array}{lll}\mathrm{BaCl}_{2}+\mathrm{Na}_{2} \mathrm{MOO}_{4} \quad 4 \times 1.2 \times 0.9 & \begin{array}{l}\text { Kurien and Ittyachen } \\ (1980)\end{array} \\ \mathrm{Pb}\left(\mathrm{NO}_{3}\right)_{2}+\left(\mathrm{NH}_{4}\right)_{2} \mathrm{MoO}_{4} & 2 & \begin{array}{l}\text { Sreedharan Pillai and } \\ \text { Ittyachen (1980) }\end{array}\end{array}$

$\mathrm{CdCl}_{2}+\mathrm{H}_{2} \mathrm{C}_{2} \mathrm{O}_{4}$

7.5

$\mathrm{CuSO}_{4} 5 \mathrm{H}_{2} \mathrm{O}+\mathrm{H}_{2} \mathrm{C}_{2} \mathrm{O}_{4}$

1.5

$\mathrm{CoCl}_{2}, 6 \mathrm{H}_{2} \mathrm{O}+\mathrm{H}_{2} \mathrm{C}_{2} \mathrm{O}_{4}$

2.0

$\mathrm{MnCl}_{2} .4 \mathrm{H}_{2} \mathrm{O}+\mathrm{H}_{2} \mathrm{C}_{2} \mathrm{O}_{4}$

$\mathrm{Na}++\mathrm{H}_{2} \mathrm{C}_{2} \mathrm{O}_{4}$

1.0

15.00

Khan et al (1976)

$$
\begin{aligned}
& \text { - do- } \\
& -\mathrm{do}- \\
& -\mathrm{do}- \\
& -\mathrm{do}-
\end{aligned}
$$

$20 \times 10 \times 6 \quad$ Patel and Venkateswara

$\mathrm{XX}+\mathrm{YClO}_{4}$

$(\mathrm{X}=\mathrm{Cl}, \mathrm{Br}, \mathrm{I}, \mathrm{OH}, \mathrm{F}$

Rao (1978b), (1981b)

and $\mathrm{Y}=\mathrm{H}, \mathrm{Na}$ )

$\mathrm{CsCl}+\mathrm{HClO}_{4}$

$\mathrm{RbCl}+\mathrm{HClO}_{4}$

- Shripathi et al (1980)

-do-

1.5 Mennicke and Dittmar (1974)

0.1 Banks et al (1973)

$\mathrm{Ba}\left(\mathrm{NO}_{3}\right)_{2}+\left(\mathrm{NH}_{4}\right)_{2} \mathrm{HPO}_{4}$ -do-

0.4

2

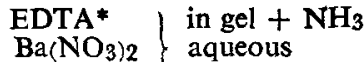

$\mathrm{KH}_{2}\left(\mathrm{PO}_{4}\right)$ solution

$\mathrm{CaX}+\mathrm{YPO}_{4}$

10

$$
\text { -do- }
$$

-do-

- do-

$\mathrm{X}=\mathrm{Cl}_{2}$. $\left(\mathrm{C}_{2} \mathrm{H}_{3} \mathrm{O}_{2}\right)_{2}$ and

$\mathbf{Y}=\mathrm{H}_{3}, \mathrm{NaH}_{2},\left(\mathrm{NH}_{4}\right)_{2} \mathrm{H}$

$\mathrm{MgSO}_{4}+\mathrm{H}_{3} \mathrm{PO}_{4}+\mathrm{NH}_{3}$

$\mathrm{Pb}\left(\mathrm{NO}_{3}\right)_{2}+\mathrm{H}_{3} \mathrm{PO}_{4}$

7.5

-do-

$8 \times 5 \times 1.5 \quad$ Konak et al (1977)

$\mathrm{Pb}\left(\mathrm{NO}_{3}\right)_{2}+\mathrm{H}_{3} \mathrm{PO}_{4}$

$1 \times 0.5$

Brezina and Havrankova (1976)

$\mathrm{Sr}\left(\mathrm{NO}_{2}\right)_{2}+\left(\mathrm{NH}_{4}\right)_{2} \mathrm{HPO}_{4} \quad 0.1$

Banks et al (1973)

$$
-\mathrm{do}-\quad-\mathrm{do}-
$$

0.05

EDTA | in gel + $\mathrm{NH}_{3} \quad \mathbf{0 . 3}$

${\mathrm{Sr}\left(\mathrm{NO}_{3}\right)_{2}}_{\mathrm{K}_{2}}$ aqueous

$-\mathrm{do}-$

- do-

*Ethylene diamine tetraacetic acid

$\mathrm{AgNO}_{3}+\mathrm{H}_{2} \mathrm{SeO}_{4}$

$\mathrm{Bi}\left(\mathrm{NO}_{3}\right)_{3}+\mathrm{H}_{2} \mathrm{SeO}_{4}$
$50 \times 3 \times 2 \quad$ Boncheva-Mladenova and Dishovsky (1979a) Boncheva-Mladenova and Dishovsky (1979b) 
Table 2. (Contd.)

\begin{tabular}{|c|c|c|c|}
\hline 1 & 2 & 3 & 4 \\
\hline \multicolumn{4}{|l|}{ Selenides } \\
\hline $\begin{array}{l}\text { CaSe } \\
\text { CuSe } \\
\text { PbSe } \\
\text { ZnSe }\end{array}$ & 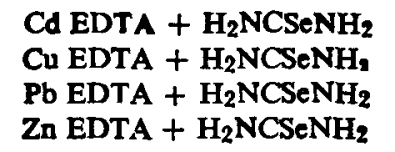 & $\begin{array}{r}100 \mu_{\mathrm{m}} \\
50 \mu_{\mathrm{m}} \\
3 \mu \mathrm{m} \\
50 \mu_{\mathrm{m}}\end{array}$ & $\begin{array}{c}\text { Blanks and Brenner (1971) } \\
\text {-do- } \\
\text {-do- } \\
\text {-do- }\end{array}$ \\
\hline \multicolumn{4}{|l|}{ Sulphates } \\
\hline $\mathrm{BaSO}_{4}$ & $\begin{array}{l}\mathrm{BaCl}_{2}+\mathrm{XSO}_{4} \\
\left(\mathrm{X}=\mathrm{Cu}, \mathrm{H}_{2}, \mathrm{Na}_{2}\right)\end{array}$ & 2 & Broower et al (1974) \\
\hline $\mathrm{CaSO}_{4}$ & $\begin{array}{l}\mathrm{CaCl}_{2}+\mathrm{XSO}_{4} \\
\left(\mathrm{H}=\mathrm{H}_{2}, \mathrm{Na}_{2}, \mathrm{NH}_{4}\right)\end{array}$ & 2.5 & Rosmalen et al (1976) \\
\hline $\begin{array}{l}\mathrm{La}\left(\mathrm{SO}_{4}\right)_{3}, \mathrm{~K}_{2} \mathrm{SO}_{4} \\
2 \mathrm{H}_{2} \mathrm{O}\end{array}$ & $\mathrm{La}\left(\mathrm{SO}_{4}\right)_{3}+\mathrm{KNO}_{3}$ & 2 & Bloor (1970) \\
\hline $\begin{array}{l}\mathrm{Pr}_{2}\left(\mathrm{SO}_{4}\right)_{3} \mathrm{~K}_{2} \mathrm{SO}_{4} \\
2 \mathrm{H}_{2} \mathrm{O}\end{array}$ & $\left.\mathrm{Pr}_{2} \mathrm{SO}_{4}\right)_{3}+\mathrm{K}_{8} \mathrm{SO}_{4}$ & 4 & -do- \\
\hline $\mathrm{SrSO}_{4}$ & $\mathrm{SrCl}_{2}+\mathrm{Na}_{2} \mathrm{SO}_{4}$ & 2 & Patel and Bhat (1973) \\
\hline \multicolumn{4}{|l|}{ Sulphides } \\
\hline $\begin{array}{l}\mathrm{CdS} \\
\mathrm{PbS} \\
\mathrm{ZnS}\end{array}$ & $\begin{array}{l}\mathrm{Cd} \text { EDTA }+\mathrm{CH}_{3} \mathrm{CSNH}_{2} \\
\mathrm{~Pb}\left(\mathrm{C}_{2} \mathrm{H}_{3} \mathrm{O}_{2}\right)_{2}+\mathrm{CH}_{3} \mathrm{CSNH}_{2} \\
\mathrm{ZnCl}_{2}+\mathrm{CH}_{3} \mathrm{CSNH}_{2}\end{array}$ & $2_{4}^{0.4} \times 2 \times 2$ & $\begin{array}{l}\text { Blank and Brenner (1971) } \\
\text { Blank (1974) } \\
\text { Patel and George (1977) }\end{array}$ \\
\hline \multicolumn{4}{|l|}{ Tartrates } \\
\hline $\mathrm{PbC}_{4} \mathrm{H}_{4} \mathrm{O}_{6}$ & $\mathrm{~Pb}\left(\mathrm{NO}_{3}\right)_{2}+\mathrm{H}_{2} \mathrm{C}_{4} \mathrm{H}_{4} \mathrm{O}_{6}$ & - & $\begin{array}{l}\text { Abdulkadhar and } \\
\text { Ittyachen (1977) }\end{array}$ \\
\hline $\begin{array}{l}\mathrm{SrC}_{4} \mathrm{H}_{4} \mathrm{O}_{6} \\
\mathrm{Sr}_{1-x} \mathrm{Ca}_{2} \mathrm{C}_{4} \mathrm{H}_{4} \mathrm{O}_{6}\end{array}$ & $\begin{array}{l}\mathrm{SrCl}_{2}+\mathrm{H}_{2} \mathrm{C}_{4} \mathrm{H}_{4} \mathrm{O}_{6} \\
\mathrm{NCl}_{2}+\mathrm{H}_{2} \mathrm{C}_{4} \mathrm{H}_{4} \mathrm{O}_{6} \\
\left(\mathrm{~N}=\mathrm{Sr}_{1-x} \mathrm{Ca}_{2 x}\right)\end{array}$ & $\begin{array}{l}50 \times 20 \times 10 \\
10 \times 6\end{array}$ & $\begin{array}{l}\text { Patel and Arora (1976) } \\
\text { Patel and Arora (1977) }\end{array}$ \\
\hline \multicolumn{4}{|l|}{ Thiocynates } \\
\hline $\mathrm{CdHgSCN}$ & $\begin{array}{l}\mathrm{Hg}_{\mathrm{g}}\left(\mathrm{NO}_{3}\right)_{2}+\mathrm{Cd}\left(\mathrm{NO}_{3}\right)_{2} \\
+\mathrm{NaSCN}\end{array}$ & 4 & Blank (1973) \\
\hline $\mathrm{ZnHgSCN}$ & $\begin{array}{l}\mathrm{Hg}\left(\mathrm{NO}_{3}\right)_{2}+\mathrm{Zn}\left(\mathrm{NO}_{3}\right)_{2} \\
+\mathrm{NaSCN}\end{array}$ & 0.5 & $-\mathrm{do}-$ \\
\hline \multicolumn{4}{|l|}{ Tungstates } \\
\hline $\begin{array}{l}\mathrm{XWO}_{4} \\
(\mathrm{X}=\mathrm{Ba}, \mathrm{Sr})\end{array}$ & $\mathrm{XCl}_{2}+\mathrm{Na}_{2} \mathrm{WO}_{4}$ & $7 \times 4 \times 2$ & Patel and Arora (1973) \\
\hline $\begin{array}{l}\mathrm{CaWO}_{4} \\
\text { Zeolites }\end{array}$ & $\mathrm{CaCl}_{2}+\mathrm{Na}_{2} \mathrm{WO}_{4}$ & $1 \times 1$ & McCauley and Roy (1974) \\
\hline Sodium A Zeolite & $\begin{array}{l}\left(100 \mathrm{gm} \mathrm{Na} \mathrm{SiO}_{3} .9 \mathrm{H}_{2} \mathrm{O}\right. \\
+100 \mathrm{mlN}\left(\mathrm{CH}_{2} \mathrm{CH}_{2} \mathrm{OH}\right)_{3} \\
+\left(80 \mathrm{gm} \mathrm{NaAlO} \mathrm{O}_{2}+\right. \\
\left.\left.100 \mathrm{ml} \mathrm{N}\left(\mathrm{CH}_{2} \mathrm{CH}_{2} \mathrm{OH}\right)_{3}\right)^{-}\right)\end{array}$ & $\begin{array}{l}40 \mu \mathrm{m} \mathrm{x} \\
40 \mu \mathrm{m}\end{array}$ & Charmell (1971) \\
\hline Sodium $\times$ zeolite & $\begin{array}{l}\left(100 \mathrm{gm} \mathrm{Na}{ }_{2} \mathrm{SiO}_{3} .9 \mathrm{H}_{2} \mathrm{O}+\right. \\
100 \mathrm{ml} \mathrm{N}\left(\mathrm{CH}_{2} \mathrm{CH}_{2} \mathrm{OH}\right)+ \\
\left(40 \mathrm{gm} \mathrm{NaA} \mathrm{N}_{2}+100 \mathrm{ml}\right. \\
\left.\mathrm{N}\left(\mathrm{CH}_{2} \mathrm{CH}_{2} \mathrm{OH}\right)_{3}\right)\end{array}$ & $60 \mu_{\mathrm{m}}$ & -do- \\
\hline VSZ zeolite & $\mathrm{Na}_{2} \mathrm{SiO}_{3} .9 \mathrm{H}_{2} \mathrm{O}+\mathrm{NaAlO}_{2}$ & $20 \mu \mathrm{m}$ & Joshi and Bhoskar (1979) \\
\hline
\end{tabular}




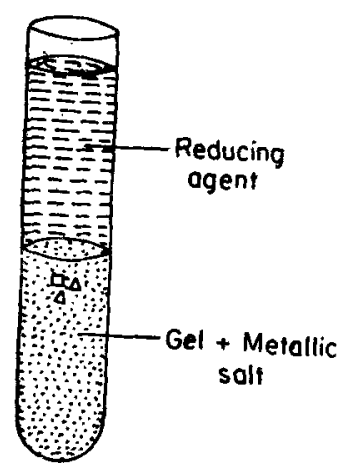

Figure 5. Schematic diagram for growing metallic crystals in gels.

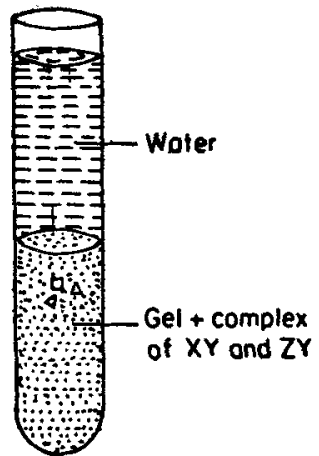

Figure 7. Schematic diagram for crystal growth by complex dilution method.

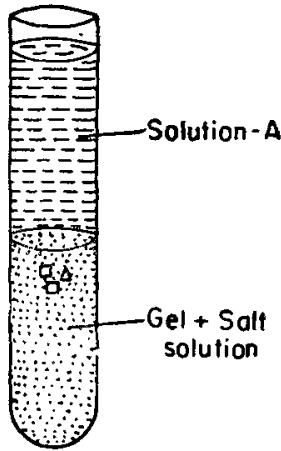

Figure 9. Schematic diagram for growing crystals by reduction of solubility (the material to be crystallized must be insoluble in solution A).

It is also possible to grow metallic crystals by this method. The first report on the growth of metallic crystals by this method has been made by Hatschek and Simon (1912). They grew gold crystals by adding $8 \%$ oxalic acid solution over the gel containing gold chloride solution. The schematic diagram, for growing metallic crystals, is shown in figure 5. Kratochvil et ol (1968) grew gold single crystals of triangular and hexagonal habits (figure 6). Lead, copper and cuprous oxide crystals have also been grown by this method. Table 2 gives a list of some of the crystals grown by the reaction method.

\subsection{Crystallization by complex dilution method}

Crystal growth by complex dilution method was first reported by O'Connor et al (1968). The general feature of this method is the existence of some soluble material which itself increases the solubility of the material of interest in a nonlinear fashion with concentration of the soluble material by complex formation in solution or by formation of a soluble double salt. In the crystal growth operation, the concentration of the combined solution is reduced by diffusion into the gel. Because the solubility of the material is a nonlinear function of the concentration of soluble material, it may reappear. The procedure for growing crystals by this method is schematically shown in figure 7 .

In the case of $\mathrm{HgS}$, the aqueous solubilities of $\alpha-\mathrm{HgS}$ and $\beta-\mathrm{HgS}$ are known to be enhanced by the presence of $\mathrm{Na}_{2} \mathrm{~S}$. Similarly, the solubilities of silver and cuprous halides are known to increase enormously in concentrated alkali halide, alkaline earth halide solutions and their respective mineral acids. Using this method, mercuric sulphide, cuprous and silver halides, and selenium. (Blank et al 1968a) have been grown. Figure 8 shows a few single crystals of laser quality cuprous 
iodide grown by complex dilution method. The list of crystals grown by this method is given in a book by Henisch (1970).

\subsection{Crystal growth by reduction of solubility}

This method is particularly suitable for growing single crystals of highly water soluble substances. Gloker and Soest (1969) first reported the growth of ammonium dihydrogen phosphate (ADP) single crystals by this method. The substance to be grown is dissolved in water and incorporated with the gel-forming solution. After setting of gel, a solution which reduces the solubility of the substance is added over the set gel (figure 9) to induce crystallization. For example, potassium dihydrogen phosphates (KDP) crystals have been grown by adding ethyl alcohol over the gel containing a saturated solution of KDP (Brezina and Havrankova 1971). The formation of the crystals is due to the reduction of solubility of KDP in the liquid phase by the diffusing alcohol. A few ferroelectric crystals of triglycine sulphate (TGS) growing in test tube are shown in figure 10. The list of crystals grown by this method is given in table 3 .

Table 3. Crystals grown by reduction of solubility of solute.

\begin{tabular}{|c|c|c|c|c|}
\hline Crystals & Solutions & \multicolumn{2}{|c|}{ Max. size (mm) } & References \\
\hline $\mathrm{Cs}_{2} \mathrm{PdCl}_{4}$ & $\begin{array}{l}\text { In gel } \\
\mathrm{Cs}_{2} \mathrm{PdCl}_{4}\end{array}$ & $\begin{array}{l}\text { Above gel } \\
\mathrm{CH}_{3} \mathrm{COCH}_{3}\end{array}$ & 5 & $\begin{array}{l}\text { Marchee and Rosmalen } \\
\text { (1977) }\end{array}$ \\
\hline $\begin{array}{l}\mathrm{Cs}_{2} \mathrm{PtCl}_{4} \cdot \mathrm{H}_{2} \mathrm{O} \\
\mathrm{KH}_{2} \mathrm{PO}_{4}\end{array}$ & $\begin{array}{l}\mathrm{Cs}_{2} \mathrm{PtCl}_{4} \mathrm{H}_{2} \mathrm{O} \\
\mathrm{KH}_{2} \mathrm{PO}_{4}\end{array}$ & $\begin{array}{l}\mathrm{CH}_{3} \mathrm{COCH}_{3} \\
\mathrm{CH}_{3} \mathrm{CH}_{2} \mathrm{OH}\end{array}$ & $\begin{array}{l}8 \\
40 \times 8 \times 7\end{array}$ & Joshi and Antony (1980) \\
\hline $\mathrm{K}_{2} \mathrm{PtCl}_{4}$ & $\mathrm{~K}_{2} \mathrm{PtCl}_{4}$ & $\mathrm{CH}_{3} \mathrm{CH}_{2} \mathrm{OH}$ & 18 & $\begin{array}{l}\text { Marchee and Rosmaien } \\
\text { (1977) }\end{array}$ \\
\hline Nacl & $\mathrm{NaCl}$ & $\begin{array}{c}\mathrm{CH}_{3} \mathrm{CH}_{2} \mathrm{OH} \\
\text { or } \mathrm{HCL}\end{array}$ & $4 \times 4 \times 4$ & Thomas Abraham (1979) \\
\hline $\mathrm{NH}_{4} \mathrm{H}_{2} \mathrm{PO}_{4}$ & $\mathrm{NH}_{4} \mathrm{H}_{2} \mathrm{PO}_{4}$ & $\mathrm{NH}_{4} \mathrm{Cl}$ & $25 \times 2$ & Glocker and Soest (1969) \\
\hline $\mathrm{Rb}_{2} \mathrm{PdCl}_{4}$ & $\mathrm{Rb}_{2} \mathrm{PuCl}_{4}$ & $\mathrm{CH}_{3} \mathrm{COCH}_{3}$ & 4 & $\begin{array}{l}\text { Marchee and Rosmalen } \\
\text { (1977) }\end{array}$ \\
\hline $\mathrm{Rb}_{2} \mathrm{PtCl}_{4}$ & $\mathrm{Rb}_{2} \mathrm{PtCl}_{4}$ & $\mathrm{CH}_{3} \mathrm{COCH}_{3}$ & $10 \times 1$ & $-\mathrm{do}-$ \\
\hline
\end{tabular}

\section{Growth mechanism}

Even though crystals can be grown in a variety of gels, the general observation is that silica gels are the best to grow good quality single crystals. A gel can be regarded as a loosely interlinked polymer. The gelling process itself takes an amount of time which can vary widely from minutes to many days, depending on the nature of the material, its temperature and history. Since gelling 


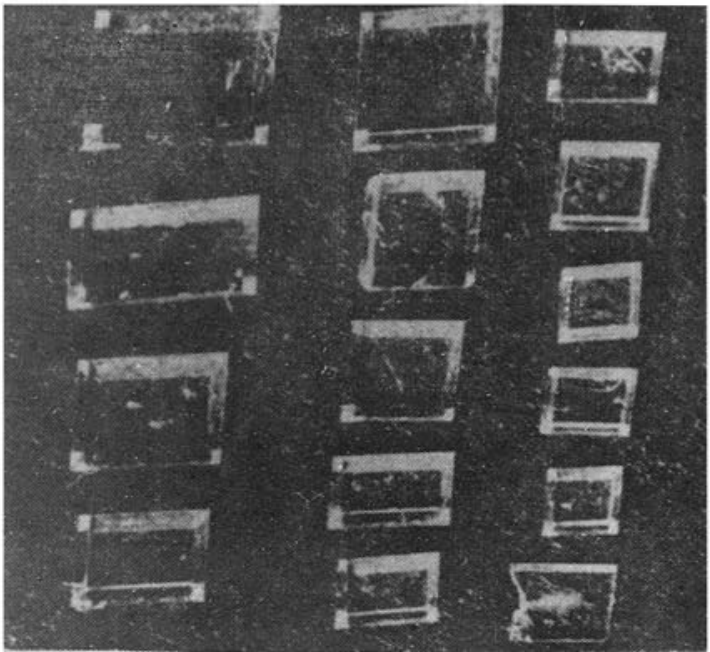

(4)

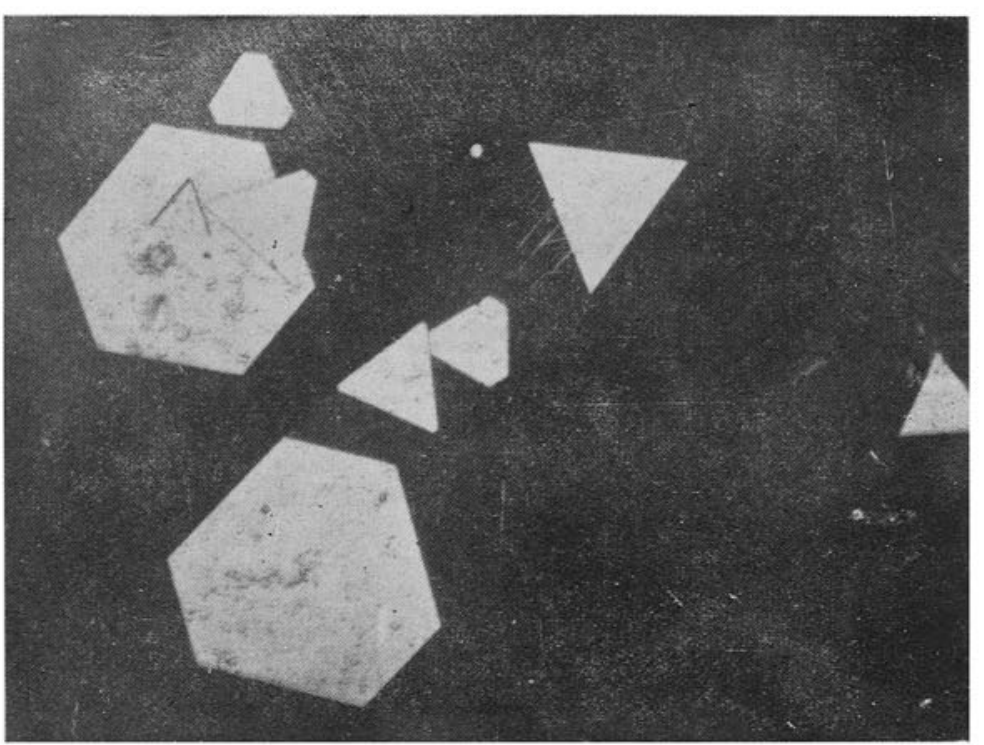

(6)

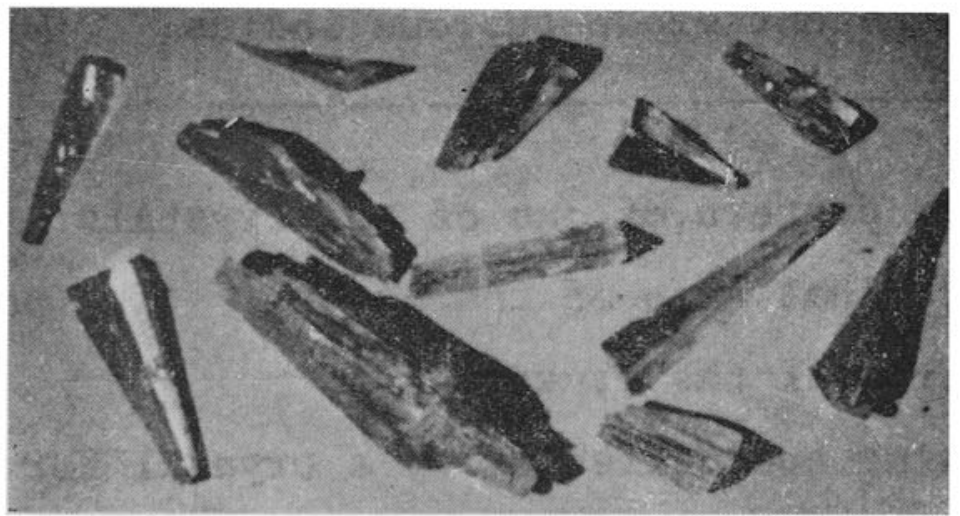

(8)

Figure 4. A few single crystals of ferroelectric lead monohydrogen phosphate $\left(\mathrm{PbHPO}_{4}\right)$ grown by reaction method (courtesy of Konak et al 1977).

Figure 6. A few single crystals of gold grown in a silica gel (courtesy of Kratochvi] et al 1968).

Figure 8. A few single crystals of laser quality cuprous iodide (CuI) grown by complex dilution method (courtesy of O'Connor and Armington 1971). 


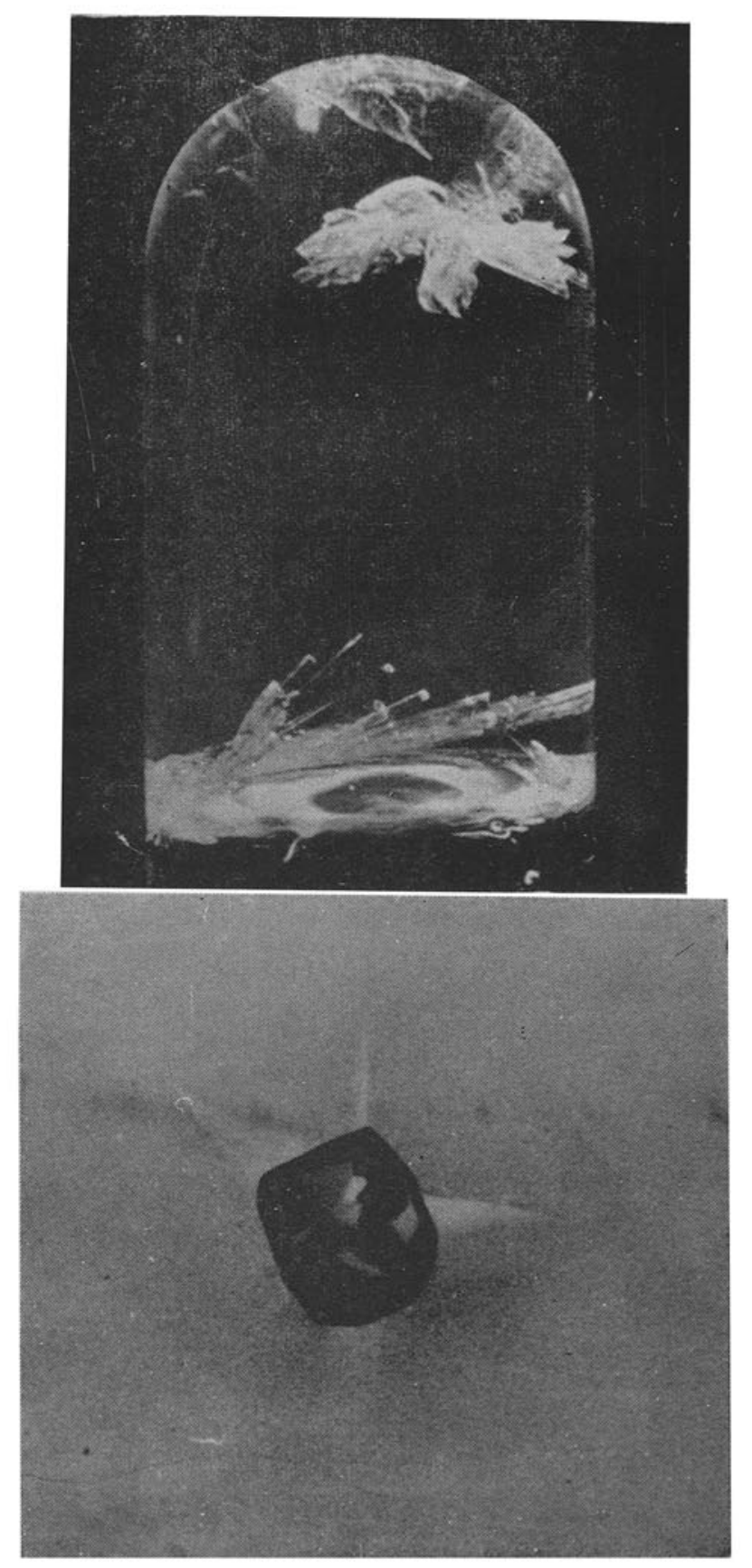

(10)

Figure 10. A few crytals of fertuelectric triglycina sulphate (TGS) are growing in test tube (courtesy of llenish jy?ily.

Figure 11. Cusns around a grouing crytuls of KClO \&after Patel and Venkateswara Rao 1977). 
is a matter of degree, quoted gelling times are always very approximate. The mechanical properties of fully developed gels can vary widely depending on the density and on the precise condition during gelling.

It has been observed that the time required for gelation is very sensitive to pH (Henisch 1970 ; Venkateswara Rao 1979). Because gelation is a gradual process, there is no unique definition of gelation time, but almost any definition will serve for comparative tests linked with a standard procedure. There is much that is still unclear about the mechanism of formation of silica gels, but it is known that two types of ions are in fact produced: $\mathrm{H}_{3} \mathrm{SiO}_{4}$ and $\mathrm{H}_{2} \mathrm{SiO}_{4}$, in relative amounts which depend on the hydrogen ion concentration. The latter is favoured by high $\mathrm{pH}$ values, is in principle more reactive, but the higher charge implies a greater degree of mutual repulsion. $\mathrm{H}_{3} \mathrm{SiO}_{4}$ is favoured by moderately low $\mathrm{pH}$ values and is held to be responsible for the initial formation of long-chain polymerization products. In due course, cross-linkages are formed between these chains, and these contribute to the sharp increase of viscosity that signals the onset of gelation. At very low $\mathrm{pH}$ values (below 3), the tendency towards polymerization is diminished, and chain formation is slowed.

Because gels are neither liquid nor solid, there is a great shortage of methods for quantitative investigations. As a result, one knows all too little about the relationships between gel structure and nucleation probability. From the SEM observations of dried silica gels (Halberstadt et al 1969) it has been found that gel consists of sheet-like structure of varying degrees of surface roughness and porosity, forming interconnected cells. The cell walls are ordinarily curved. From the SEM pictures of the silica gel it has been estimated that the cell walls seen in dense gels $\left(0.4 \mathrm{M} \mathrm{Na}_{2} \mathrm{SiO}_{3}\right)$ have pores from less than $0.1 \mu$ to $0.5 \mu$, compared with values from less than $0.1 \mu$ to $4 \mu$ in low density $\left(0.2 \mathrm{M} \mathrm{Na}_{2} \mathrm{SiO}_{3}\right)$ gels. The cell walls are thicker for the dense gels. The $\mathrm{pH}$ during gelling has a profound influence on gel structure changes from a distinctly box like network to a structure consisting of loosely bound platelets which appear to lack crosslin ages; the cellular nature becomes less distinct (Halberstadt et al 1969).

The gel medium prevents turbulence and remaining chemically inert, provides a three-dimensional structure, which permits the reagents to diffuse at a desirable controlled rate. That the absence of turbulence is beneficial in growing good crystals has been demonstrated by repeating the experiments in an inert powder $\left(\mathrm{TiO}_{2}\right)$ instead of gel (Henisch et al 1965). In addition, the gel provides a frame work of nucleation sites and yet is soft enough to yield mechanically to the growing crystal. However, as soon as a crystal has reached a certain size, the gel splits off partially and forms one or more small cusp-like cavities, as shown in figure 11 . It is interesting to note that the crystal does not cease to grow where these cusp-like cavities occur.

From the observation of the growth process, it was concluded that in the absence of convection, the only mechanism available for the supply of solute to the growing crystal is diffusion. Frank (1950) has developed equations which give a description of diffusion-controlled growth rates. Gel systems provide new applications of this theory. The growth kinetics of gel-grown crystals follow a parabolic law which is characteristic of one-dimensional diffusion controlled process (Hanoka 1969). 
In the growth systems which depend on the diffusion of one reactant through a gel incorporating the other reagent it is observed that the growth rate is greatest near the gel-solution interface where the concentration gradients are high; away from the interface, the gradients are relatively low. Corresponding to different growth rates, the dislocation density is also different (Patel and Venkateswara Rao 1979a). This suggests strongly that the growth rate itself determines the number of defects grown into the crystal even in the absence of foreign impurities. Occasionally, crystals grown in gels are found to have dislocation densities less than $10^{3} / \mathrm{cm}^{2}$. The high degree of perfection of these crystals has also been demonstrated by means of x-ray Laue diffraction patterns and etch patterns (O'Connor and Armington 1971; Patel and Venkateswara Rao 1979a).

It is apparent that crystals growing in a gel either displace the gel as they grow (Patel and Venkateswara Rao 1977) or incorporate the gel (Patel and Bhat 1973). In the case of gel displacing, cusps can be seen around the growing crystal as shown in figure 11, while in the other case, since the crystals incorporate the gel as they grow, final crystals turn turbid instead of being transparent. In the case of crystals growing in fissures in the gel, a clear boundary between opaque crystal grown in the gel and a clear crystal grown in the solution can be seen (Nickl and Henisch 1969). Normally the progressive deterioration of crystal quality indicates an increasing incorporation of gel in the passage of time which eventually leads to the destruction of the perfect facets observed on small crystals.

Crystals such as calcite grown in the normal way as reported by Nickl and Henisch (1969), are well-formed rhombohedra but are almost invariably turbid due mainly to silica inclusions. It is clear from these results that the silica network which constitutes the gel is incorporated into the growing crystals more or less in fact. In this way, calcite differs greatly from other gel-grown crystals (e. $g$. potassium perchlorate), which are surprisingly free from silica contamination. Crystals of calcite grow at the boundaries between gel and liquid are turbid to the extent to which they overlap the gel and clear to the extent to which they grow in solution. This suggests that calcite and other crystals which may behave in a similar way should not be grown in gels at all. They should be grown in solution, if possible without losing the general benefits of the gel method. The solution (i.e. $\mathrm{H}_{2} \mathrm{O}$ ) should thus be in a cavity so that solute concentrations within it may be regulated by the demands of the growing crystal. Nickl and Henisch (1969) have reproposed a hybrid method which uses gel as a diffusion barrier while the crystals grow in a gel-free region. An improved experimental design devised by Patel and Venkateswara Rao (1980) can also be used for the same purpose.

\section{Nucleation control}

Crystals growing in a gel system compete with one another for the solute atoms. This competition limits their size and perfection. It is therefore obviously desirable to suppress nucleation until only a few crystals are formed. There are some methods with which nucleation in gels can be controlled to some extent. They are devised by 
(a) Using suitable reactants, (b) using gels prepared with various acids,

(c) changing the gel structure, (d) using intermediate neutral gel, and

(e) concentration programming.

\subsection{Using suitable reactants}

Out of various combinations of reactants which can be used to yield the required product crystal, only a few are found to be suitable to achieve controlled nucleation. In the case of growth of potassium perchlorate crystals, various reactants were used, however a combination of potassium chloride and perchloric acid has been found to considerably reduce the nucleation density. Even in this case, the nucleation centres are less and size of the crystals is bigger in gels mixed with perchloric acid than in gels mixed with potassium chloride (Patel and Venkateswara Rao 1979a). Tarun Bandyopadhyay and Asok de (1977) found that the nucleation density is reduced by using calcium chloride and ammonium carbonate as the reactants instead of calcium chloride and sodium carbonate for the growth of calcite crystals. Recently, Shiojiri et al (1978) reported that in the case of the growth of thallium iodide crystals, the nucleation density was much lower and the size of the crystals was much larger in the gels mixed with sodium iodide than in the gels mixed with thallium nitrate. The difficulties in growing single crystals of sulphides in gels can be traced to excessive nucleation when compounds such as sodium sulphide or hydrogen sulphide are used as the source of sulphide ions. The employment of an organic sulphur compound, thioacetamide, as sulphur ion donor overcomes this difficulty by its slow and controllable rate of hydrolysis which makes available only a limited number of sulphide ions at any time. Blank et al (1968b) have tried various organo-sulphur compounds to yield sulphide ions but crystals grown using thioacetamide are fewer in number, bigger and purer as compared to those grown with other sulphur compounds. In the case of the growth of selenides of lead and cadmium, nucleation density can be reduced to some extent using lead EDTA and cadmium EDTA instead of their respective chlorides or acetates (Blank and Brenner 1971).

\subsection{Using gels prepared with various acids}

After selecting the best combination of reactants with a particular acid set gel, it is necessary to use the same reactants with various acid set gels in order to reduce the nucleation density and grow bigger crystals. Only a few crystals have been grown in various acid set gels. Neodymium carbonate crystals have been grow $n$ in acetic and hydrochloric acid set gels (McCauley and Gehrhardt 1970). When acetic acid set gels were used to grow these crystals, only white-caked precipitate formed whereas hydrochloric acid set gels yielded good quality single crystals. For the growth of potassium perchlorate crystals (Patel and Venkateswara Rao 1979a), four mineral acids (perchloric, hydrochloric, sulphuric and nitric) and four organic acids (citric, tartaric, acetic and propionic) were used to form gels and it is found that the perchloric acid set gels yielded the best results. Regarding the growth of lead iodide crystals, the lowest nucleation density was obtained when acetic acid set gels were used (Patel and Venkateswara Rao 1981a). 


\subsection{Changing the gel structure}

It is possible to change the gel structure and reduce the nucleation density by changing gel $\mathrm{pH}$ (McCauley and Gehrhardt 1970), gel density and gel aging (Patel and Venkateswara Rao 1978a). In general, increased gel density and gel pH decrease the nucleation density to a considerable extent but the final crystals are of poor quality. On the contrary, gel aging reduces the nucleation density and hence the total number of crystals, without affecting their quality. The decrease of nucleation centres at higher densities of gel and gels aged for longer periods is due to the fact that these two parameters reduce the cell size and consequently the rate of diffusion of ions into the gel. The decrease in nucleation density at higher $\mathrm{pH}$ values may be due to the improper formation of gel cells at higher $\mathrm{pH}$ values of gels (Patel and Venkateswara Rao 1978a).

\subsection{Using intermediate neutral gel}

This method involves the preparation of a gel containing one of the reactants in the bottom of a test tube as in the usual test tube method. However, a second gel, called the intermediate neutral gel or the reaction gel is formed over the first gel and the second reactant is then poured over it. The neutral gel will slow down the reaction between the reactants and reducing the number of nuclei. This method was first used by Blank and Brenner (1969) to grow lead and thallous and cuprous oxide single crystals. McCauley and Roy (1974) and McCauley and Gehrhardt (1970) have also used the same method to grow calcium carbonate, neodymium carbonate and calcium tungstate crystals. More recently Patel and Venkateswara Rao (1978) used this method to study the effect of intermediate neutral gel on nucleation and growth of potassium perchlorate single crystals. It has been found that the nucleation density decreases as the height of the intermediate gel increases.

\subsection{By concentration programming}

In this procedure, the concentration of diffusing reactant is initially kept below the level at which nucleation is known to occur and is then increased gradually in a series of small steps. It is considered that with very dilute reactants the amount of material diffused through the gel is small and hence smaller is the supersaturation rate. Under these circumstances, a few nuclei are formed. On increasing the concentration, further growth of the existing nuclei is preferred to the formation of additional ones. Crystals grown by this method are more perfect and larger than those grown otherwise. The method has been successfully applied for the control of nucleation in the case of calcium tartrate, cuprous tartrate, iodides of lead and thallium, calcium carbonate, cadmium oxalate, potassium perchlorates tungstates of barium and strontium etc. (Henisch 1970; Patel and Venkateswara Rao 1978a; Patel and Arora 1973).

\section{Morphologies of various gel grown single crystals}

Crystals with various habits are important not only commercially but also in studying their physical properities. In gel growth, various habits of crystals can be 
obtained by changing concentration of feed solutions, crystallization temperature and gel structure, by adding impurities and by using various types of gels. In addition to these, various habits in different regions of gel are also observed in some cases.

\subsection{Habit modification by changing the concentration of feed solution, crystalli- zation temperature and gel structure}

In the case of calcium tungstate crystals grown in gels, high calcium concentrations favoured the growth of clear spherulites, whereas high tungstate concentrations resulted in opaque spherulities. During the growth of neodymium carbonate, sodium carbonate incorporated gel enhanced the formation of dendrites and spherulites, whereas neodymium chloride incorporated gel favoured the growth of rhombic plates and clusters of plates (McCauley and Gehrhardt 1970). With regard to calcium carbonate growth (Tarun Bandyopadhyay and Asok de 1977) when the strengths of feed solutions were from 0.2 to $0.3 \mathrm{M}$, the crystals were of rhombohedral habit and with the edges having wavy and ripple like features at concentrations of 0.4 to $0.6 \mathrm{M}$. Further increase in the strengths of feed solutions to $1.0 \mathrm{M}$ and more, generated a large number of nucleation centres with dendritic crystallization. The morphology of both barium and strontium sulphate single crystals grown under similar conditions was the same. The change in the concentration of feed solutions had no effect on the morphology of the grown crystals. However, it was observed that there was a considerable effect of the growth temperature on their morphology. For example, in the case of strontium sulphate, all the crystals grown at about $35^{\circ} \mathrm{C}$ had $\{011\}$ and $\{102\}$ as their habit faces, whereas the crystals grown at about $20^{\circ} \mathrm{C}$ developed $\{022\}$ habit faces in addition to the usual $\{011\}$ and $\{102\}$ faces (Patel and Bhat 1973). During the growth of potassium perchlorate (Patel and Venkateswara Rao 1979b) at lower concentrations of about $1 \mathrm{~N}$ of both the feed solutions, almost all the crystals developed predominant $\{101\}$ and $\{210\}$ faces and at higher concentrations $(2 N)$ of both the feed solutions, the crystals, were in the form of needles with predominant $\{210\}$ faces. By increasing the concentration of one of the reactants to around $4 N$ and decreasing the concentration of the other to around $1 \mathrm{~N}$, the crystals grown were of rhombic shape with two $\{0(i 1\}$ faces bounded by four $\{210\}$ faces. It was also observed that the growth rates along [010] direction increased with temperature. Cuprous chloride crystals grown in the temperature range $22-40^{\circ} \mathrm{C}$ were tetrahedral and those grown at $50^{\circ} \mathrm{C}$ were long needles (Armington and O'Connor 1968). The elongated $\mathrm{C}$-axis growth was attributed to the relatively low $\mathrm{pH}$ of the gel medium in the case of ADP crystals (Glocker and Soest 1969). With respect to the growth of calcite crystals, decrease in the $\mathrm{pH}$ of gel resulted in the development of spherulites ( $\mathrm{pH} \mathrm{10.5)} \mathrm{into} \mathrm{feathery} \mathrm{polycrystalline} \mathrm{aggregates} \mathrm{(} \mathrm{pH} 9$ to 10.5) and finally into single crystals of rhombic habits ( $\mathrm{pH} 7$ to 9). (McCauley and Roy 1974).

\subsection{Habit modification by adding various impurities}

As in "solution growth" in gel growth also, it is possible to change crystal habit by adding impurities. Various habits of calcite were obtained by adding 
impurities of $\mathrm{Mg}, \mathrm{Sr}, \mathrm{Ni}$ and $\mathrm{Ba}$ in various proportions during the growth of these crystals (McCauley and Roy 1974). Gypsum crystals grown in silica gel in the presence of inorganic compounds were needle-shaped, while the addition of organic compounds altered the habit into a more stubby modification (Rosmalen et al 1976). Crystals grown in pure agar gels were equally shaped. But when small amounts of hydrochloric acid were added, needles developed. Perfect rhombohedrashaped crystals of calcite have been obtained by adding a saturated solution of sacroboise to the feed solutions (Barta and Zemlicka 1971). The addition of ammonium chloride to the gel system lead to the formation of single crystal needles of calcium tungstate (McCauley and Gehrhardt 1970).

\subsection{Habit modification by using various types of gels}

The morphology of minerals (for example gypsum) which have grown within muds (for example bentonite clay) and other sediments has assumed importance because of the possibility of a correlation between the physico-chemical parameters of the surrounding media and mineral habits. Since the primary concern in attempting to understand such a relationship is to simulate natural conditions in the laboratory, efforts have been made to grow crystals within natural muds (Cody 1976). A comparison of crystals of calcium sulphate dihydrate grown in two different gel media, sodium silicate gel and bentonite clay gel, showed that the two media affect crystal habit and surface topography differently. Those crystals grown in silica gel at $40^{\circ} \mathrm{C}$ and $\mathrm{pH} 6-7.5$ consisted of elongated prisms with relatively smooth crystal faces, and they were often twinned. Crystals grown in bentonite gel at the same temperature and similar $\mathrm{pH}$ were tabular with a wide variety of kinks, steps and pits on their surfaces, and were never twinned. This suggests that bentonite gel more closely simulates natural mud as a support medium for crystal growth than silica gel (Cody and Shanks 1974).

\subsection{Various habits obtained at different regions of gel}

In the case of lead molybdate growth, there were different regions inside the gel where lead molybdate crystals of various habitats were formed. Near lead nitrate solution, polyhedral pyramidal crystals were formed. Octahedral bipyramidal crystals and platelets were formed in the central region and near the ammonium molybdate solution respectively (Sreedharan Pillai and Ittyachen 1977). The habit modification was explained to be due to the excess arrival of lead and molybdate ions in their respective zones. The morphologies of barium molybdate crystals in the U-tubes could be divided into three groups depending on all the crystallization zones where they formed in the tubes. The needle and cruciform-shaped crystals were formed towards the U-tube arm containing the barium chloride solution. The well-developed star-like dendritic and octahedral crystals formed very close to the central crystallization zone. The crystals formed near the sodium molybdate solution appeared to be aggregates of small crystallites (Cho et al 1977). In the growth of lead monohydrogen phosphate (LHP) crystals (Brezina and Havrankova 1976), crystallization zones were observed in which 
crystals of various habits were obtained. In the region very close to lead nitrate reactant solution, lead nitrogen phosphate $\left(\mathrm{Pb}_{4}\left(\mathrm{NO}_{3}\right)_{2}\left(\mathrm{PO}_{4}\right)_{2}, 2 \mathrm{H}_{2} \mathrm{O}\right)$ crystals were formed. After this region, platelets, spherulites and rosettes of LHP were observed. Near to phosphoric acid reactant solution, needle-like crystals were observed. In copper iodates also, a surprisingly wide variety of crystal morphology was observed at various regions in the gel (Nassau et al 1973).

\section{Studies on gel grown single crystals}

Much work has been done on lead iodide crystals to understand its band structure (Henisch 1970) and polytypism (Mahesh Chand and Trigunayt 1975; Meera Rao and Srivastava 1978). These studies had been greatly impeded because of lack of suitable specimens and besides many contradictory results were reported. With the gel technique, it was found possible to grow not only flat plates, but specimens thick enough to permit measurements of the refractive index in all crystal directions. The measurements showed that the dielectric polarization is mainly electronic in character. When gel-grown neodymium carbonate crystals were examined by transmitted light microscopy, they exhibited a highly symmetric domain structure and a strain birefringence (McCauley and Gehrhardt 1970). It was concluded that the domains might be magnetic in origin. The electrical resistivity of gel-grown lead sulphide crystals was found to be $8.4 \times 10^{-4} \mathrm{ohm} \mathrm{cm}$ at $25^{\circ} \mathrm{C}$ (Blank et al 1968) in comparison with the values $8.0 \times 10^{-2} \mathrm{ohm} \mathrm{cm}$ for untreated natural galena and $7.0 \times 10^{-3} \mathrm{ohm} \mathrm{cm}$ for "synthetic" lead sulphide (Brebrick and Scanlon 1954). Test on a single filament of gel-grown silver acetate revealed stresses of $1 \cdot 25 \times 10^{6} \mathrm{psi}$ in bending without any fracture or permanent deformation (Boulin and Ellis 1970). Silver trihydrogen periodate has been investigated because of its antiferroelectricity at low temperatures with a complicated phase transition near $231^{\circ} \mathrm{K}$. Contrary to former heat anomaly measurements (Bartschi 1945), gel-grown crystals of $\mathrm{Ag}_{2} \mathrm{H}_{3} \mathrm{IO}_{6}$ showed for the first time the two-stage character of transition (Arend and Perison 1971). Dendrites of metallic lead have been used for metallurgical studies by Bedarida (1964). Lead hydroxy iodide has been prepared for the first time in single crystal form by gel technique. Optical absorption spectra of the crystals have been studied at about $430 \mu \mathrm{m}$. It also gives the spectral response of the photoconductivity. The low frequency $\left(10^{4} \mathrm{C} / \mathrm{Sc}\right)$ dielectric constant is about 10.5 , and the magnetic susceptibility is $-0.25 \mathrm{~b} \times 10^{-6} \mathrm{~g}$. They showed a faint but stable bluish white cathodoluminescence (Henisch 1970). The quality of gel-grown potassium dihydrogen phosphate (KDP) crystals is judged according to dielectric properties measured in the vicinity of the ferroelectric phase transition. The values of maximum permittivity, spontaneous polarization and $\triangle T$ of these crystals (Brezina and Havrankova 1971) are comparable with those of very good samples of KDP grown by solution method. Nassau et al (1973) and Abraham et al (1973) have reported detailed studies on structural, optical and magnetic properties of transition metal iodates. Lead monohydrogen phosphate (LHP) is a typical representative of the family of ferroelectric schultemites undergoing a second order structural phase transition at $3.75^{\circ} \mathrm{C}$. Principal refractive indices, birefringence, indicatrix orientation data of the permittivity and spontaneous polarization of 
dislocation free single crystals of ferroelectric LHP have already been reported (Konak et al 1977; Smutny and Fousek 1980). The temperature dependence of birefringence is found to be related to the ferroelectric transition. Studies on the gel-grown lead monohydrogen arsenate (LHA) crystals (Brezina et al 1975) suggest a ferroelectric transition similar to that of LHP. Detailed studies on the electrical and optical properties of gel grown AgI single crystals have been reported by Govindacharyulu and Bose (1978). The thermochromic compound, cuprous mercuric iodide, has been of great interest because of its usefulness as an erasable, high density infrared storage medium. The material exhibits hysteresis in its phase transition (Chivian 1976) which serves as the basis of infrared recording applications.

\section{Conclusions}

Considering the amount of data available on crystal growth in gel media and the importance of growing crystals at ambient temperatures, a survey of the method in general and subsequent modifications along with the experimental results reported so far are presented in this review article. The gel growth technique with its various modifications appears to be quite promising for the production of highly perfect single crystals of a variety of materials.

A general assessment of the method and its potentialities is not yet possible, but recent experiments have yielded results which should prove useful to other workers in this field. A great deal of work remains to be done to document and explain the detailed nature of gel structure which will be displaced by the growing crystal as in the case of potassium perchlorate or incorporation of gel into the new solid by crystal growth as in the case of calcite. Many important crystals such as $\mathrm{CaWO}_{4}, \mathrm{CaF}_{2}$. $\mathrm{HgI}, \mathrm{CaCO}, \mathrm{PbS}, \mathrm{ZnS}, \mathrm{PbHPO}_{4}, \mathrm{Ag}_{2} \mathrm{H}_{3} \mathrm{IO}_{6}$ etc. can be grown in various types of gels and by adding impurities in order to decrease nucleation density and to grow various shapes of highly perfect single crystals. Out of a large number of gel-grown single crystals, properties of only a few have been studied. Comparative studies of gel-grown single crystals with those grown by other method are worth attempting in order to probe into and take advantage of the characteristics and peculiarities of gel-grown crystals. The further development of the gel method will certainly depend on the extent to which its mechanism can be understood and controlled.

\section{Acknowledgements}

The authors are grateful to Dr G K Shivakumar for his many helpful comments and suggestions on the manuscript. The authors also thank Professior H K Henisch, Dr A F Armington, Dr B Brezina, Dr P Krotochvil and their coworkers for allowing us to include some of the results of their research work in the present review article. One of us (AVR) wishes to thank the Council of Scientific and Industrial Research, New Delhi, India for the award of a fellowship. 


\section{References}

Abdulkhadar M and Ittyachen M A 1977 J. Cryst. Growth 39365

Abdulkhadar M and Ittyachen M A 1980 J. Cryst. Growth 48149

Abraham S C, Sherwood R C, Bernstein J L and Nassau K 1973 J. Solid State Chem. 8274

Arend H and Perison J 1971 Mater. Res. Bull. 61205

Arend $\mathrm{H}$ and Huber W 1972 J. Cryst. Growth 12179

Armington A F and O'Connor J J 1967 AFCRL (USA) 3251

Armington A F and O'Connor J J 1968 Mater. Res. Bull. 2907

Armington A F and O'Connor J J 1971 Mater. Res. Bull. 7613

Banks E, Chianelli R and Pintchokshy F 1973 J. Cryst. Growth 18185

Barta C and Zemlica J 1971 J. Cryst. Growth 10158

Bartschi P 1945 Hel. Phys. Acta. 18267

Bedarida F 1964 Periodico Mineral 331

Bernstein J L, Shiever J W and Nassau K $1976 \mathrm{~J}$. Appl. Crystallogr. 9357

Blank Z, Brenner W and Okamoto Y 1968a J. Cryst. Growth 3/4 372

Blank Z, Brenner W and Okamoto Y 1968b Mater. Res. Bull. 3555

Blank Z and Brenner W 1969 Nature (London) 22279

Blank Z and Brenner W 1971 J. Cryst. Growth 11255

Blank Z 1973 J. Cryst. Growth 18281

Blank Z 1974 J. Cryst. Growth 26215

Bloor D 1970 J. Cryst. Growth 71

Boncheva-Mladenova Z and Dishousky N 1979a J. Cryst. Growth 47467

Boncheva-Mladenova Z and Dishovsky N 1970b J. Cryst. Growth 4782

Boulin D and Ellis W C 1970 J. Cryst. Growth 6290

Brebrick R F and Scanlon W W 1954 Phys. Rev. 96598

Brezina B and Havrankova 1971 Mater. Res. Bull. 87537

Brezina B, Smutny F and Fousek J 1975 Czech. J. Phys. B25 1411

Brezina B and Havrankova M 1976 J. Cryst. Growth 34248

Brouwer G, van Rosmalen G M and Bennema P 1974 J. Cryst. Growth 23228

Charnell J F 1971 J. Cryst. Growth 8291

Chivian J S 1976 Mater. Res. Bull. 8785

Cho S A, Gomer J A, Camisotti R and Ohep J C 1977 J. Mater. Sci. 12816

Cody R D and Shanks, H R 1974 J. Cryst. Growth 23275

Cody R D 1976 Geol. Soc. Am. Bull.

Desai C C and Rai J L 1980 J. Cryst. Growth 50562

Fells L W and Firth J B 1926 Proc. R. Soc. (London) $\mathbf{A 1 1 2} 468$

Fisher L W and Simons 1926 Am. Mineral 11200

Frank F C 1950 Proc. R. Soc. A201 586

Glocker D A and Soest I F 1969 J. Chem. Phys. 513143

Govindacharyulu P A and Bose D N 1978 Indian J. Phys. 53191

Halberstadt E S, Henisch H K, Nickl J and White E W 1969 J. Colloid Interface Sci. 29469

Hanoka J I 1969 J. Appl. Phys. 402694

Hatschek E 1911 Kolloid Z. 813

Hatschek E and Simon 1912 Kolloid Z. 10265

Henisch H K, Dennis J and Hanoka J 11965 J. Phys. Chem. Solids 26493

Henisch H K 1970 Crystal Growth in gels (Pennsylvania State Univ. Press)

Holmes H N 1917 J. Phys. Chem. 21709

Joshi M S and Bhosker B T 1979 J. Cryst. Growth 47654

Joshi M S and Antony A V 1980 J. Mater. Sci. 231

Joshi M S and Trivedi S G 1980 Kristall Tech. (in press)

Khan A S, Devore T C and Reed W F 1976 J. Cryst. Growth 35327

Kock E J and Hopp H 1980 Phys. Stat. Sol. A57 569

Konak C, Smutny F, Brezina B and Budik L 1977 Zech. J. Phys. B27 1313

Kratochvil P, Sprusil B and Heyrovsky L 1968 J. Cryst. $3 / 4360$

Kurien K V and Ittyachen M A 1979 J. Cryst. Growth 47743

Leckebusch R and Recker K 1972 J. Cryst. Growth 13/14 276 
Leckebusch R 1974 J. Cryst. Growth 2374

Liesegang R E 1896 Chemishe Fernwirkung Noch Sep. Von. V Dusseldrof, Verlog Von Ed. Le Segang. Phot. Archiv. V 21221

Mahesh Chand and Trigunayat G C 1977 J. Cryst. Growth 39299

Marchee W G J and Rosmalen G M V 197? J. Cryst. Growth 39358

Martin S A and Haendler H N 1978 J. Appl. Crystallogr. 1162

McCauley J W and Gehrhardt H M 1970 Report AMMRC TR-70-13 (AD-710 236) 25

McCauley J W and Roy R 1974 Am. Miner. 59947

Meera Rao and Srivastava O N 1978 J. Phys. D11 919

Mennicke S and Dittmar W 1974 J. Cryst. Growth 26197

Mohanan Pillai K and Ittyachen M A 1978 Pramana 10613

Morse H W and Donnay J D H 1931 Bull. Soc. Francaise de Mineralogie 5419

Nakada I, Ishizuku H and Ishihara N 1976 Jpn. J. Appl. Phys. 15919

Nassau K, Copper A S, Shiever J W and Prescott B E 1973 J. Solid State Chem. 8260

Nickl H J and Henisch H K 1969 J. Electrochem. Soc. 1161258

O'Connor J J, Dipietro M A, Armington A F and Rubin B 1968 Nature (London) 21268

O'Connor J J and Armington A F 1971 Mater. Res. Bull. 6765

Patel A R and Arora S K 1973 J. Cryst. Growth 18199

Patel A R and Arora S K 1976 J. Mater. Sci. 11843

Patel A R and Arora S K 1977 J. Cryst. Growth 37343

Patel A R and Bhat H L 1973 J. Cryst. Growth 18288

Patel A R and Venkateswara Rao A 1977 J. Cryst. Growth 38288

Patel A R and Venkateswara Rao A 1978a J. Cryst. Growth 43351

Patel A R and Venkateswara Rao A 1978b Indian J. Pure Appl. Phys. 16544

Patel A R and Venkateswara Rao A 1979a J Cryst. Growth 47213

Patel A R and Venkateswara Rao A 1979b Kristall Tech. 14151

Patel A R and Venkateswara Rao A 1980 J. Cryst. Growth 49589

Patel A R and Venkateswara Rao A 1981a Indian J. Pure Appl. Phys. 19685

Patel A R and Venkateswara Rao A 1981b Kristall Tech. 161007

Patel S M and George V 1977 J. Elect. Mater. 6499

Rosmalen G N V, Marchee W G J and Bennema P 1976 J. Cryst. Growth 35169

Shiojiri M, Kaito C, Saito Y, Murakami M and Kawamoto 1978 J Cryst. Growth 4361

Shiever J W and Nassau K 1972 Mater. Res. Bull. 7613

Shripathi T, Bhat H L and Narayanan P S 1980 J. Mater. Sci. 153095

Smutny $\mathrm{F}$ and Fousek 1980 Ferroelectrics (In Press)

Sreedharan Pillai K and Ittyachen M A 1977 J. Cryst. Growth 39287

Sreedharan Pillai K and Ittyachen M A 1980 Indian J. Pure Appl. Phys. 1878

Strong C L 1962 Sci. Am. 206155

Suib S L and Weller P F $1980 \mathrm{~J}$. Crystal Growth 48155

Tarun Bandyopadhyay and Asok de 1977 Indian J. Earth Sci. 495

Thomas Abraham 1979 (Private communication)

Vand V, Henisch H K and McCauley J W 1963 Acta Crystallogr. A16 137

Venkateswara Rao A 1979 Gel growth and characterization of $\mathrm{KClO}_{4}$ and PbI $\mathrm{P}_{2}$ crystals, Ph. D. Thesis. Sardar Patel University, India. 